\title{
The New Compound of (2R, 4S)-N-(2, 5-difluorophenyl)-4- Hydroxy-1-(2, 2, 2-Trifluoroacetyl) Pyrrolidine-2-Carboxamide to Mediate the Expression of Some Apoptosis Genes by the HepG2 Cell Line
}

\author{
Mahnaz Ramezani ${ }^{1}$, Mahin Ramezani ${ }^{2,3}$, Ali Darekordi ${ }^{3}$, Gholamhossein \\ Hassanshahi ${ }^{4}$, Mohammad Reza Mirzaei ${ }^{4,5 *}$
}

\begin{abstract}
Objectives: Hepatocellular carcinoma is one of the most frequent cancers worldwide, for the treatment of which various therapy protocols and drugs have been introduced; however, none of them has suppressed cancer tissues completely. New research programs have been developed on cancer and the accompanied effects of novel synthesized compounds on cancer cell lines. Our latest reports on the molecular basis of cancer revealed a pattern of changes in gene expression triggered in the cancer pathway. Methods: HepG2 cell lines were cultured under similar conditions in both test and control groups. The $\mathrm{IC}_{50}$ concentration of the (2R, 4S)-N-(2, 5-difluorophenyl)-4-hydroxy-1-(2, 2, 2-trifluoroacetyl) pyrrolidine-2-carboxamide compound was used in the treatment group. After 48 hours from the culture, the expressional profiles of apoptosis pathway genes ( 84 genes) were studied using the PCR array method. Results: The findings demonstrated that the expression of some apoptosis-related genes pertaining to TNF, BCL2, IAP, and caspase families was regulated by (2R, 4S)-N-(2, 5-difluorophenyl)-4-Hydroxy-1-(2, 2, 2-Trifluoroacetyl) Pyrrolidine-2-Carboxamide. In the same vein, an alteration was observed in the expression of both pro-apoptotic and anti-apoptotic genes associated with the extrinsic and intrinsic apoptosis signaling pathways. Conclusions: According to the data obtained, the pyrrolidine-2-carboxamide compound was demonstrated to be able to regulate the apoptotic activities of HepG2 cells by affecting both pro-apoptotic and anti-apoptotic relevant genes.
\end{abstract}

Keywords: Pyrrolidine-2-carboxamide compound- HepG2 cells- Apoptosis pathway

Asian Pac J Cancer Prev, 20 (5), 1457-1462

\section{Introduction}

Cells are considered as the basic structural and functional units of human life. Normally, older cells undergo division and proliferate in order to generate newer ones; in addition, they are destroyed as a result of apoptosis in a complicated process, so equilibrium exists between live and dead cells, under normal circumstances (Hanahan and Weinberg, 2000). The malignancy of liver cancer is among the six most frequent cancer types, being considered the third cause of cancer deaths worldwide (Moy et al., 2013). Unfortunately, the incidence rate of the various types of liver cancer has increased in developing countries in recent years. There exists no efficient treatment for liver cancer to date, so the development of advanced treatments for the disease will be highly valued. Accordingly, a wide variety of synthetic pro-apoptotic and anti-apoptotic compounds has been developed for the treatment of various tumors, including liver cancer (Hersey and Zhang, 2001).

$\mathrm{N}$-heterocyclic structures are the major classes of such compounds that play a major role in medicinal chemistry and in particular in drug synthesis (Ten Holte et al., 2001). Organofluorine compounds (organoFs) have been utilized by a large number of pharmaceutical, agrochemical, and drug industries in the past few decades (Hudlicky, 1979). From among them, trifluoroacetimidoyl chlorides substituted molecules have been investigated extensively, with the indication that these fluorinated structures demonstrate interesting biological activities (Polshettiwar and Varma, 2010; Romero et al., 2015).

Based on the introduction above, the authors of this article synthesized the new derivative of (2R, 4S)-N-aryl-4-hydroxy-1-(2, 2, 2-trifluoroacetyl)

${ }^{1}$ Immunology of Infectious Diseases Research Center, ${ }^{4}$ Molecular Medicine Research Center, Research Institute of Basic Medical Sciences, ${ }^{5}$ Department of Clinical Biochemistry, Faculty of Medicine, Rafsanjan University of Medical Sciences, ${ }^{3}$ Department of Chemistry, Faculty of Science, Vali-e-Asr University of Rafsanjan, Rafsanjan, ${ }^{2}$ Nanotechnology Research Center, Mashhad University of Medical Sciences, Mashhad,Iran.*For Correspondence: mirzaeemr@gmail.com 
pyrrolidine-2-carboxamides (Darehkordi and Ramezani, 2017) (Figure 1). Apoptosis is defined as a homeostatic cellular event by which cell populations are preserved in tissues. The apoptosis phenomenon occurs normally as cells proliferate or become aged. Apoptosis is also involved actively in defensive processes, principally in the pathogenesis of a variety of human diseases including, viral infections, autoimmune diseases, and cancer (Norbury and Hickson, 2001). It is well established that some anticancer drugs act by inducing apoptosis in order to exert their cytotoxic effects (Ferreira et al., 2002).

Synthetic compounds which possess cytotoxic properties have apoptosis-inducing potentials in numerous types of human cancer cells. The study of apoptosis-inducing effects under both normal and modified conditions is of high significance (Hersey and Zhang, 2001). Thus, the present study was conducted aimed at investigating the effects of the $(2 \mathrm{R}, 4 \mathrm{~S})-\mathrm{N}-(2$, 5-difluorophenyl)-4-Hydroxy-1-(2, 2, 2-Trifluoroacetyl) Pyrrolidine-2-Carboxamide derivative on cellular apoptosis in human hepatocellular carcinoma cells (HepG2 cells). For this purpose, the authors of this article used RT2 Profiler PCR Arrays to detect the profile of gene expression changes in response to the new derivative of pyrrolidine-2-carboxamide in HepG2 cells.

\section{Materials and Methods}

\section{Chemical compound preparation}

The powdered sample was provided by dissolving $5 \mathrm{mg}$ of the chemical compound in $1 \mathrm{~mL}$ of DMSO (dimethyl-sulphoxide) to achieve an appropriate concentration of $5 \mathrm{mg} / \mathrm{mL}$. Next, the produced stock solution was filtered through a $0.45 \mu \mathrm{M}$ filter, before use in each assay. In the following step, $400 \mu \mathrm{L}$ of the stock solution was mixed up gently and enriched with $600 \mu \mathrm{L}$ of RPMI 1640 at appropriate concentrations $(125 \mu \mathrm{g})$, which was required for examinations by serial dilution (Ramezani et al., 2017).

\section{The cell culture method}

A sample of HepG2 cells was provided from the National Cell Bank of Iran (the Pasteur Institute of Iran, Tehran). The cells were cultured in a $25 \mathrm{~mL}$ culture flask in the RPMI 1640 medium (Gibco, Pasteur Institute, Tehran, Iran). Next, they were supplemented with $10 \%$ fetal bovine serum (FBS) (Gibco, USA), penicillin-streptomycin (100 $\mathrm{U} / \mathrm{mL}$ ) and incubated at $37^{\circ} \mathrm{C}$ in a humidified atmosphere containing $95 \% \mathrm{O}_{2}$ and $5 \% \mathrm{CO}_{2}$. As already mentioned in brief, cell growth inhibition $\left(\mathrm{IC}_{50}\right.$ ) was calculated to be $50 \%$ for pyrrolidine-2-carboxamide after 48 hours $(62.5 \mu \mathrm{g} / \mathrm{mL})$ (Ramezani et al., 2017). The nonmalignant cells (L929) were also cultured under similar conditions in the RPMI 1640 medium containing $5 \%(\mathrm{v} / \mathrm{v})$ of fetal bovine serum (FBS) and 100 units/mL of penicillin-streptomycin. The cultures were left overnight and then incubated at the required concentrations of the pyrrolidine derivative $(62.5 \mu \mathrm{g} / \mathrm{mL})$ for 48 hours to be examined by the realtime Profiler PCR Array (The RT2 Profiler PCR Array, SABiosciences, USA).

\section{RT2 Profiler PCR array}

The RT2 Profiler PCR Array (SABiosciences, USA) was performed to analyze the expression of a panel of genes involved in the apoptosis pathway (Human Apoptosis PCR Array, RT2 Strand Kit, SABiosciences, USA) together with 5 housekeeping genes. This Real-Time PCR (RT-PCR) kit contained 84 apoptosis-related genes, 5 housekeeping genes, as well as 3 RNA and PCR quality controls. The cells received either a relative concentration of the new therapeutic compound of $(2 \mathrm{R}, 4 \mathrm{~S})-\mathrm{N}-(2$, 5-difluorophenyl)-4-Hydroxy-1-(2, 2, 2-Trifluoroacetyl) Pyrrolidine-2-Carboxamide) or the control medium alone and were kept at $37^{\circ} \mathrm{C}$. Following 48 hours from the treatment, the cells were rinsed with PBS and harvested through centrifugation for the purpose of RNA isolation. The total RNA content was extracted using the Qiagen kit (USA) in accordance with the manufacturer's recommended protocol. The purity and fidelity of the RNA were examined using the spectrophotometric method (by the calculation of the $260 / 280 \mathrm{~nm}$ absorbance ratio) and running on the $1.5 \%$ agarose gel, with electrophoresis utilized to assess the purity and integrity of RNA. The first strand of cDNA was generated by the RT2 First Strand kit (Qiagen, USA) from 1.0 $\mu \mathrm{g}$ of the total RNA for 96-well plates. An ABI, Step 1 plus RT2 PCR Detection System (ABI, Step 1 plus, USA), was applied for the real-time PCR analysis. For each PCR array plate, an experimental cocktail was produced using $998.4 \mu \mathrm{L}$ of the RT2 $\mathrm{qPCR}$ master mix, $96 \mu \mathrm{L}$ of the first strand cDNA's synthesis reaction, and $825.6 \mu \mathrm{L}$ of ddH2 $\mathrm{O}$. The $20 \mu \mathrm{L}$ reaction of the experimental cocktail was aliquoted into each PCR array well. The RT2 qPCR thermal cycling program included one cycle at $95^{\circ} \mathrm{C}$ for $10 \mathrm{~min}, 40$ cycles at $95^{\circ} \mathrm{C}$ for $15 \mathrm{~s}$, $60^{\circ} \mathrm{C}$ for $40 \mathrm{~s}$, and $72^{\circ} \mathrm{C}$ for $30 \mathrm{~s}$ (Mirzaei et al., 2014).

\section{Statistical analysis}

The authors of this article analyzed the data quantitatively by employing the $2^{-(\Delta \Delta \mathrm{Ct})}$ method, with the threshold cycle (CT) values exported and analyzed using the web-based software of RT2 Profiler PCR Array Data Analysis, version 3.5 (HTTP:// PCR data analysis. sabiosciences.com/pcr/array analysis. PHP). The fold changes of the relevant genes were calculated by the $2^{-(\Delta \Delta C t)}$ formula. The PCR array was performed in triplicate for each sample, i.e. the extract-treated sample and the control sample.

\section{Results}

\section{The effects of pyrrolidine derivatives on apoptosis-related} genes

To explore the expression of the critical key genes involved in cellular apoptosis in response to being exposed to the pyrrolidine derivative $(0.5 \mathrm{mg} / \mathrm{mL})$ for 24 hours, a quantitative Real-Time qPCR method was utilized by employing the Human Apoptosis RT² Profiler PCR Array. For this purpose, numerous members of gene families, including TNF/TNFR proteins, BCL2 and BAG proteins, BIR proteins, TRAF proteins, and caspases were analyzed. The genes exhibiting fold changes up to two (fold-regulation $>2$ ) and less than 0.5 (fold-regulation $<-2$ ) 
DOI:10.31557/APJCP.2019.20.5.1457

Expression of Apoptosis Genes Expression by Pyrrolidine-2-Carboxamide

Table 1. Gene's up/down-Regulated after Pyrrolidine-2Carboxamide Treatment

\begin{tabular}{|c|c|c|c|}
\hline $\begin{array}{l}\text { Gene } \\
\text { symbol }\end{array}$ & Protein/gene name & Activity & $\begin{array}{c}\text { Fold } \\
\text { changes }\end{array}$ \\
\hline$A K T 1$ & $\begin{array}{l}\text { V-at murine thymoma } \\
\text { viral oncogene homolog } \\
1\end{array}$ & $\begin{array}{l}\text { Anti- } \\
\text { apoptosis }\end{array}$ & 42.5 \\
\hline$B A G 3$ & $\begin{array}{l}\text { BCL2-associated } \\
\text { athanogene } 3\end{array}$ & $\begin{array}{l}\text { Anti- } \\
\text { apoptosis }\end{array}$ & 6.15 \\
\hline$B A X$ & $\begin{array}{l}\text { BCL2-associated X } \\
\text { protein }\end{array}$ & Pro-apoptosis & -7.07 \\
\hline$B C L 2$ & B-cell CLL/lymphoma 2 & Pro-apoptosis & -9.19 \\
\hline$B C L 2 A 1$ & BCL2-related protein A1 & Pro-apoptosis & 23.21 \\
\hline$B C L 2 L 11$ & $\begin{array}{l}\text { BCL2-like } 11 \text { (apoptosis } \\
\text { facilitator) }\end{array}$ & Pro-apoptosis & -17.94 \\
\hline$B C L A F 1$ & $\begin{array}{l}\text { BCL2-associated } \\
\text { transcription factor } 1\end{array}$ & Pro-apoptosis & 5.15 \\
\hline$B F A R$ & $\begin{array}{l}\text { Bifunctional apoptosis } \\
\text { regulator }\end{array}$ & $\begin{array}{l}\text { Anti- } \\
\text { apoptosis }\end{array}$ & 5.56 \\
\hline$B I D$ & $\begin{array}{l}\text { BH3 interacting domain } \\
\text { death agonist }\end{array}$ & Pro-apoptosis & -4.21 \\
\hline$B I K$ & $\begin{array}{l}\text { BCL2-interacting killer } \\
\text { (apoptosis-inducing) }\end{array}$ & Pro-apoptosis & -36.51 \\
\hline$B I R C 2$ & $\begin{array}{l}\text { Baculoviral IAP repeat } \\
\text { containing } 2\end{array}$ & $\begin{array}{l}\text { Anti- } \\
\text { apoptosis }\end{array}$ & 30 \\
\hline$B I R C 3$ & $\begin{array}{l}\text { Baculoviral IAP repeat } \\
\text { containing } 3\end{array}$ & $\begin{array}{l}\text { Anti- } \\
\text { apoptosis }\end{array}$ & 7.585 \\
\hline BIRC6 & $\begin{array}{l}\text { Baculoviral IAP repeat } \\
\text { containing } 6\end{array}$ & $\begin{array}{l}\text { Anti- } \\
\text { apoptosis }\end{array}$ & -25.17 \\
\hline$B N I P 1$ & $\begin{array}{l}\text { BCL2/adenovirus E1B } \\
\text { 19kDa interacting } \\
\text { protein } 1\end{array}$ & $\begin{array}{l}\text { Anti- } \\
\text { apoptosis }\end{array}$ & -8.95 \\
\hline$B N I P 3$ & $\begin{array}{l}\text { BCL2/adenovirus E1B } \\
\text { 19kDa interacting } \\
\text { protein } 3\end{array}$ & $\begin{array}{l}\text { Anti- } \\
\text { apoptosis }\end{array}$ & -70.13 \\
\hline$B R A F$ & $\begin{array}{l}\text { V-RAF murine sarcoma } \\
\text { viral oncogene homolog } \\
\text { B1 }\end{array}$ & $\begin{array}{l}\text { Anti- } \\
\text { apoptosis }\end{array}$ & -18.48 \\
\hline CASP10 & $\begin{array}{l}\text { Caspase } 10 \text {, apoptosis- } \\
\text { related cysteine } \\
\text { peptidase }\end{array}$ & Pro-apoptosis & -11.81 \\
\hline Gene symbol & Protein/gene name & Activity & $\begin{array}{c}\text { Fold } \\
\text { changes }\end{array}$ \\
\hline CASP14 & $\begin{array}{l}\text { Caspase } 14 \text {, apoptosis- } \\
\text { related cysteine } \\
\text { peptidase }\end{array}$ & Pro-apoptosis & -26.86 \\
\hline$C A S P 3$ & $\begin{array}{l}\text { Caspase } 3 \text {, apoptosis- } \\
\text { related cysteine } \\
\text { peptidase }\end{array}$ & Pro-apoptosis & 9.57 \\
\hline CASP5 & $\begin{array}{l}\text { Caspase } 5 \text {, apoptosis- } \\
\text { related cysteine } \\
\text { peptidase }\end{array}$ & Pro-apoptosis & 34.33 \\
\hline CASP8 & $\begin{array}{l}\text { Caspase } 8 \text {, apoptosis- } \\
\text { related cysteine } \\
\text { peptidase }\end{array}$ & Pro-apoptosis & -18.82 \\
\hline$C D 40 L G$ & CD40 ligand & $\begin{array}{l}\text { Anti- } \\
\text { apoptosis }\end{array}$ & -47.94 \\
\hline$C I D E B$ & $\begin{array}{l}\text { Cell death-inducing } \\
\text { DFFA-like effector } b\end{array}$ & Pro-apoptosis & -12.94 \\
\hline FASLG & $\begin{array}{l}\text { Fas ligand (TNF } \\
\text { superfamily, member 6) }\end{array}$ & Pro-apoptosis & 17.42 \\
\hline$I G F 1 R$ & $\begin{array}{l}\text { Insulin-like growth } \\
\text { factor } 1 \text { receptor }\end{array}$ & $\begin{array}{l}\text { Anti- } \\
\text { apoptosis }\end{array}$ & -9.75 \\
\hline
\end{tabular}

Table 1. Continued

\begin{tabular}{|c|c|c|c|}
\hline $\begin{array}{l}\text { Gene } \\
\text { symbol }\end{array}$ & Protein/gene name & Activity & $\begin{array}{c}\text { Fold } \\
\text { changes }\end{array}$ \\
\hline RIPK2 & $\begin{array}{l}\text { Receptor-interacting } \\
\text { serine-threonine } \\
\text { kinase } 2\end{array}$ & Anti-apoptosis & -4.53 \\
\hline$T N F$ & Tumor necrosis factor & Pro-apoptosis & 25.99 \\
\hline TNFRSF10A & $\begin{array}{l}\text { Tumor necrosis factor } \\
\text { receptor superfamily, } \\
\text { member } 10 \mathrm{a}\end{array}$ & $\begin{array}{c}\text { Death domain } \\
\text { proteins }\end{array}$ & -85.66 \\
\hline TNFRSF10B & $\begin{array}{l}\text { Tumor necrosis factor } \\
\text { receptor superfamily, } \\
\text { member } 10 \mathrm{~b}\end{array}$ & $\begin{array}{c}\text { Death domain } \\
\text { proteins }\end{array}$ & -74.28 \\
\hline TNFRSF1A & $\begin{array}{l}\text { Tumor necrosis factor } \\
\text { receptor superfamily, } \\
\text { member 1A }\end{array}$ & $\begin{array}{c}\text { Death domain } \\
\text { proteins }\end{array}$ & -5.2 \\
\hline TNFSF 10 & $\begin{array}{l}\text { Tumor necrosis factor } \\
\text { (ligand) superfamily, } \\
\text { member } 10\end{array}$ & Pro-apoptosis & -23.63 \\
\hline TP53 & Tumor protein p53 & Pro-apoptosis & 36.38 \\
\hline TP73 & Tumor protein $\mathrm{p} 73$ & Pro-apoptosis & -4.19 \\
\hline
\end{tabular}

were regarded to be expressed differentially (Table 1). Table 3 shows the fold regulation of the examined genes by the PCR array. From among the genes detected, 8 of them were upregulated, yet 14 of them were downregulated (Figure 2). Accordingly, the genes that underwent altered expression included TNF/TNFR family members, such as FASLG, LTA, TNF, TNFRSF10A, and TNFRSF21 (Table $2)$. The results indicated that the BCL2 and BAGn family members, including BAG4, BAX, BCL2A1, and BCL2L11 also displayed some degrees of changes in their change expression. The BIR family members, such as BIRC3 and XIAP together with TRAF family members were shown to have been altered. However, no expression alteration was observed in the caspase family members, including CASP10, CASP14, CASP3, CASP4, CASP2, and CASP5 (Table 2). The findings in Table 1 demonstrated that in addition to genes, such as BAD (BCL2-associated agonist of cell death) and BAG4 (BCL2-associated athanogene 4), BCL2-like1 and BCL2-like11 (the apoptosis facilitator), Baculoviral IAP repeat containing the 6 (BIRC6), BCL2interacting killer (apoptosis-inducer), BCL2/adenovirus

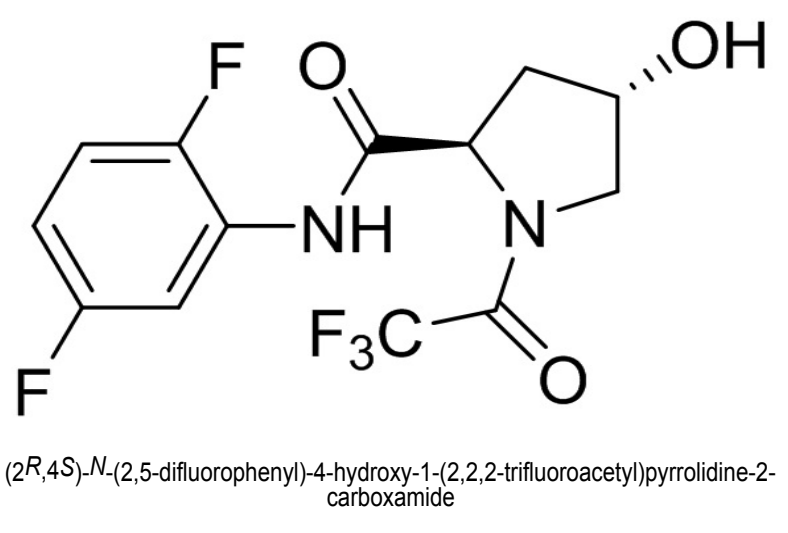

Figure 1. The Chemical Composition Image of (2R, 4S)-N-(2, 5-difluorophenyl)-4-Hydroxy-1-(2, 2, 2-Trifluoroacetyl) Pyrrolidine-2-Carboxamide (C13H11F5N2O3) (Darehkordi and Ramezani, 2017). 
Table 2. A Complete List of Apoptotic Genes' Expression Alteration in HepG2 Cell Line

\begin{tabular}{|c|c|c|c|c|}
\hline No & $\begin{array}{l}\text { Regulation } \\
\text { intensity }\end{array}$ & $\begin{array}{l}\text { Position in } \\
\text { PCR panel }\end{array}$ & $\begin{array}{l}\text { Gene } \\
\text { symbol }\end{array}$ & $\begin{array}{l}\text { fold } \\
\text { regulation }\end{array}$ \\
\hline 1 & $\uparrow \uparrow \uparrow \uparrow \uparrow \uparrow$ & A02 & $A K T 1$ & 42.5 \\
\hline 2 & $\uparrow \uparrow$ & A06 & $B A G 3$ & 6.157 \\
\hline 3 & $\uparrow \uparrow \uparrow \uparrow \uparrow$ & A12 & $B C L 2 A 1$ & 23.21 \\
\hline 4 & $\uparrow \uparrow$ & B02 & $B C L 2 L 10$ & 2.9737 \\
\hline 5 & $\uparrow \uparrow$ & B04 & $B C L 2 L 2$ & 2.5396 \\
\hline 6 & $\uparrow \uparrow$ & B05 & $B C L A F 1$ & 5.5132 \\
\hline 7 & $\uparrow \uparrow \uparrow \uparrow \uparrow$ & B10 & $B I R C 2$ & 30.0046 \\
\hline 8 & $\uparrow \uparrow$ & B11 & $B I R C 3$ & 7.585 \\
\hline 9 & $\uparrow \uparrow$ & $\mathrm{C} 08$ & NOD1 & 2.399 \\
\hline 10 & $\uparrow \uparrow$ & D03 & CASP3 & 9.577 \\
\hline 11 & $\uparrow \uparrow \uparrow \uparrow \uparrow$ & D05 & CASP5 & 34.33 \\
\hline 12 & $\uparrow \uparrow$ & D07 & CASP7 & 3.6785 \\
\hline 13 & $\uparrow \uparrow$ & D10 & $C D 40$ & 3.9391 \\
\hline 14 & $\uparrow \uparrow \uparrow \uparrow$ & E08 & FASLG & 17.423 \\
\hline 15 & $\uparrow \uparrow \uparrow \uparrow \uparrow$ & F06 & $T N F$ & 25.9996 \\
\hline 16 & $\uparrow \uparrow \uparrow \uparrow \uparrow$ & G06 & TP53 & 36.3841 \\
\hline 17 & $\uparrow \uparrow \uparrow \uparrow$ & E08 & FASLG & 17.423 \\
\hline 18 & $\leftrightarrow$ & A01 & $A B L 1$ & -1.3157 \\
\hline 19 & $\leftrightarrow$ & $\mathrm{A} 03$ & $A P A F 1$ & -1.1866 \\
\hline 20 & $\leftrightarrow$ & A05 & $B A G 1$ & 1.0105 \\
\hline 21 & $\leftrightarrow$ & A08 & $B A K 1$ & 1.4554 \\
\hline 22 & $\leftrightarrow$ & A10 & $B C L 10$ & -1.1522 \\
\hline 23 & $\leftrightarrow$ & B09 & NAIP & 1.4413 \\
\hline 24 & $\leftrightarrow$ & B12 & $X I A P$ & -1.1584 \\
\hline 25 & $\leftrightarrow$ & $\mathrm{C} 04$ & $B N I P 2$ & -1.4684 \\
\hline 26 & $\leftrightarrow$ & $\mathrm{C} 06$ & $B N I P 3 L$ & 1.0441 \\
\hline 27 & $\leftrightarrow$ & D04 & CASP4 & -1.0249 \\
\hline 28 & $\leftrightarrow$ & D06 & CASP6 & -1.9333 \\
\hline 29 & $\leftrightarrow$ & D09 & CASP9 & 1.6979 \\
\hline 30 & $\leftrightarrow$ & E03 & $C R A D D$ & 1.6262 \\
\hline 31 & $\leftrightarrow$ & E04 & $D A P K 1$ & 1.436 \\
\hline 32 & $\leftrightarrow$ & E07 & $F A S$ & -1.083 \\
\hline 33 & $\leftrightarrow$ & E07 & $F A S$ & -1.083 \\
\hline 34 & $\leftrightarrow$ & E10 & $H R K$ & -1.5854 \\
\hline 40 & $\downarrow \downarrow$ & A09 & $B A X$ & -7.0745 \\
\hline 41 & $\downarrow \downarrow$ & A11 & $B C L 2$ & -9.1946 \\
\hline 42 & $\downarrow \downarrow \downarrow \downarrow$ & B03 & $B C L 2 L 11$ & -17.9496 \\
\hline 43 & $\downarrow$ & B07 & $B I D$ & -4.2116 \\
\hline 44 & $\downarrow \downarrow \downarrow \downarrow \downarrow$ & B08 & $B I K$ & -36.5133 \\
\hline 45 & $\downarrow \downarrow \downarrow \downarrow \downarrow$ & $\mathrm{C} 01$ & BIRC6 & -25.1791 \\
\hline 46 & $\downarrow$ & $\mathrm{C} 02$ & BIRC8 & -2.1114 \\
\hline 47 & $\downarrow \downarrow$ & $\mathrm{C} 03$ & $B N I P 1$ & -8.9569 \\
\hline 49 & $\downarrow \downarrow \downarrow \downarrow$ & $\mathrm{C} 07$ & $B R A F$ & -18.4811 \\
\hline 50 & $\downarrow$ & $\mathrm{C} 09$ & CARD6 & -2.7074 \\
\hline 51 & $\downarrow$ & $\mathrm{C} 10$ & CARD 8 & -3.6587 \\
\hline 52 & $\downarrow$ & $\mathrm{C} 11$ & CASP1 & -2.1089 \\
\hline 53 & $\downarrow \downarrow \downarrow$ & $\mathrm{C} 12$ & CASP10 & -11.881 \\
\hline
\end{tabular}

Table 2. Continued

\begin{tabular}{|c|c|c|c|c|}
\hline No & $\begin{array}{c}\text { Regulation } \\
\text { intensity }\end{array}$ & $\begin{array}{l}\text { Position in } \\
\text { PCR panel }\end{array}$ & Gene symbol & $\begin{array}{l}\text { fold } \\
\text { regulation }\end{array}$ \\
\hline 54 & $\downarrow \downarrow \downarrow \downarrow$ & D08 & CASP8 & -18.8262 \\
\hline 55 & $\downarrow \downarrow \downarrow \downarrow \downarrow$ & D11 & $C D 40 L G$ & -47.9471 \\
\hline 56 & $\downarrow$ & D12 & CFLAR & -3.6587 \\
\hline 57 & $\downarrow \downarrow \downarrow$ & E02 & $C I D E B$ & -12.9436 \\
\hline 58 & $\downarrow$ & E05 & $D F F A$ & -3.6587 \\
\hline 59 & $\downarrow$ & E09 & GADD45A & -3.6587 \\
\hline 60 & $\downarrow \downarrow$ & E11 & $I G F 1 R$ & -9.7576 \\
\hline 61 & $\downarrow$ & F02 & $M C L 1$ & -3.6587 \\
\hline 62 & $\downarrow$ & F03 & NOL3 & -3.6587 \\
\hline 63 & $\downarrow$ & F05 & RIPK2 & -4.5391 \\
\hline 64 & $\downarrow$ & F09 & TNFRSF11B & -3.6587 \\
\hline 65 & $\downarrow \downarrow$ & F10 & TNFRSF1A & -5.2093 \\
\hline 66 & $\downarrow$ & F11 & TNFRSF 21 & -3.6587 \\
\hline 67 & $\downarrow$ & F12 & TNFRSF 25 & -3.6587 \\
\hline 68 & $\downarrow$ & G02 & TNFRSF9 & -3.6587 \\
\hline 69 & $\downarrow \downarrow \downarrow \downarrow \downarrow$ & G03 & TNFSF10 & -23.6357 \\
\hline 70 & $\downarrow$ & G04 & $C D 70$ & -3.6587 \\
\hline 71 & $\downarrow$ & G05 & TNFSF8 & -3.6587 \\
\hline 72 & $\downarrow$ & G07 & TP53BP2 & -3.6587 \\
\hline 73 & $\downarrow$ & G08 & TP73 & -4.1904 \\
\hline 74 & $\downarrow$ & G09 & $T R A D D$ & -3.6587 \\
\hline
\end{tabular}

E1B 19kDa interacting protein 3(BINP3), V-RAF murine sarcoma viral oncogene homolog B1 (BRAF), CASP10, 2,8 , and 14 were downregulated strongly after further treatments. In addition, the tumor necrosis factor-alpha receptor superfamily, member 10a and b (TNFRSF10A, B), CD40 ligand, as well as the Cell death-inducing DFFA-like effector (CIDEA) were shown to have been down-expressed in response to this derivative (Table 1).

\section{Discussion}

Despite extensive research conducted on the treatment of liver cancer to reduce its incidence rate, this type of malignancy is still considerably frequent in the world (Siegel et al., 2014). The present study examined the apoptotic effects of pyrrolidine derivatives on human hepatoma (HepG2) cells. In a similar study, the cytotoxic effects of this derivative were explored on HepG2 cells by the MTT assay, and the cells were double-stained with Annexin-V and PI for the in-vitro flow cytometric detection of apoptotic cells, with the results indicating that it induced HepG2 cell apoptosis significantly at $125 \mu \mathrm{L}$ concentrations after 48 hours (Ramezani et al., 2017). To achieve the research goals, the authors of this article extended the mentioned study making use of the PCR array technology. Apart from developing cancer treatment methods, another way of fighting cancer could be the designing of new therapeutic agents, which act though 


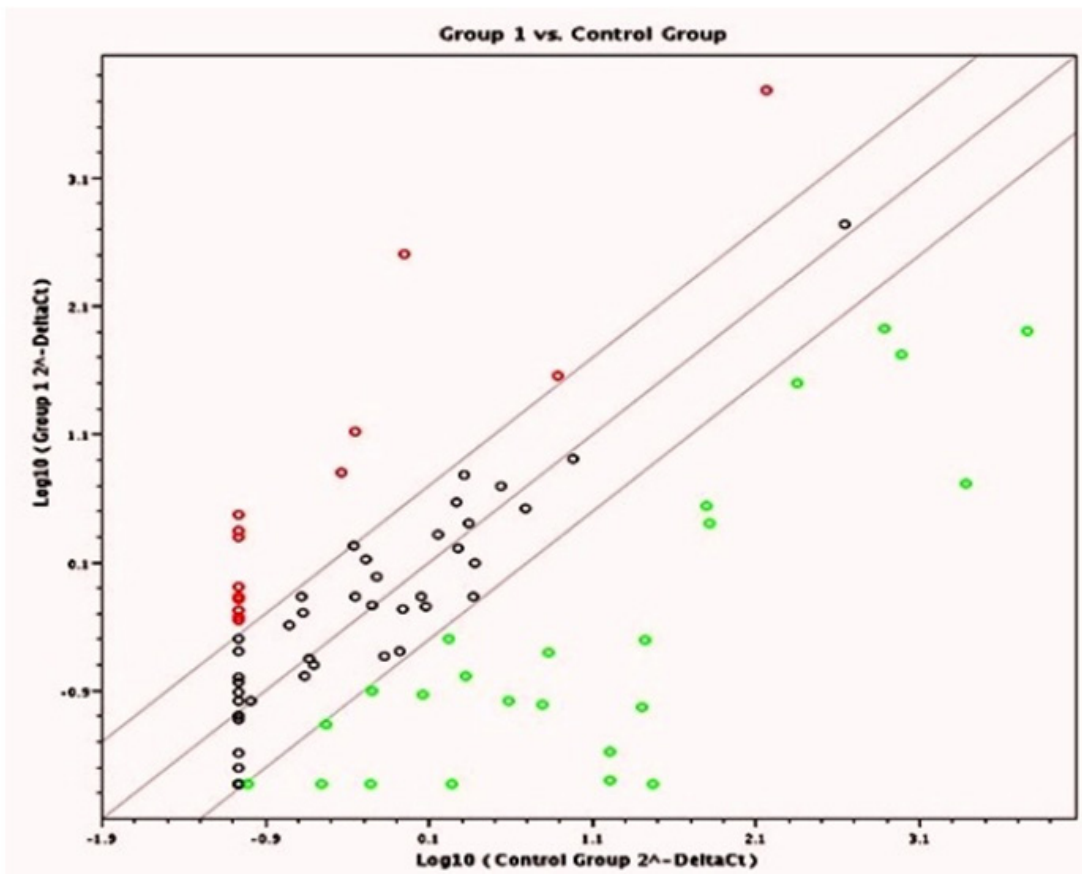

Figure 2. The Scatter Plot Created in the PCR Array Data Analysis Web Portal Compares the Normalized Expression of Each Gene on PCR Array between 2 Groups. The upper left section (red dots) indicates upregulated genes, while the lower right section (green dots) indicates downregulated genes and the black dots indicates unchanged expressions of the genes.

either the upregulation of pro-apoptotic molecules or the downregulation of anti-apoptotic molecules (Fesik, 2005; Call et al., 2008). In addition, to explore the underlying molecular mechanisms of apoptosis induced by the pyrrolidine derivative, the PCR array technology was used in this article. Research results indicate that pyrrolidine is able to modify apoptosis-induced gene expression (Ramezani et al., 2017). To better understand molecular mechanisms, we specified the expression of apoptosis-related genes by a quantitative real-time PCR array technology and found out that this derivative reduced cell viability and induced apoptosis. This PCR array included a wide range of gene families involved in apoptosis, such as TNF ligands and their receptors, BCL-2 members, caspase, IAP, and TRAF (Table 1). The array data showed that the expression of many genes was connected with the extrinsic and intrinsic apoptosis signaling pathways (Table 2). The perforingranzyme-dependent killing of the cells was changed significantly together with these changes, with this being remarkably important in the case of anti-apoptotic genes and supporting the assumption that this pyrrolidine derivative was able to exert its apoptotic effects mostly by the downregulation of these genes (Table 1).

As Table 2 shows, the expression of Bcl-2, being known for its anti-apoptotic properties, decreased significantly (Reed, 2008). In the same vein, the expression of other anti-apoptotic molecules, including Bcl2L1, Bcl2L11, IGF1R, BRAF, and CD40LG decreased dramatically. Furthermore, in addition to the two main apoptotic pathways, i.e. the extrinsic and the intrinsic ones, an additional pathway has been detected that includes T-cell mediated cytotoxicity and perforin-granzyme, being dependent on the killing of the cells (Igney and Krammer, 2002). Although the Bcl-2 gene family plays a significant role in both pro-apoptotic and anti-apoptotic pathways, it could be assumed that the reduction in the expression of caspases has been probably due to the fact that these two pathways have been able to affect each other (Table 1) (Reed, 2008). Moreover, the expression of caspases 3 and 5 has increased significantly, with this implying that perforin-granzyme has been further initiated by the cleavage of caspase 3 , leading to DNA fragmentation, the degradation of cytoskeletal and nuclear proteins, and the formation of apoptotic bodies (Table 1) (Martinvalet et al., 2005). In the present study, the expression of FASLG 1 and TNF receptor death domains increased, thereby playing a significant role in signaling pathways, in order of transferring the death signal from the cell surface to the intracellular space (Rubio-Moscardo et al., 2005). In the same vein, P53 played a pivotal role by mediating cellular death after damage, with its pro-apoptotic function having depended on transcription factors, including c-Myc (Table 1) (Marnett and Plastaras, 2001). In the present study, it was demonstrated that the expression of the p53 gene increased significantly, yet another membrane p53 family, i.e. the p 73 gene, was downregulated in response to this derivative (Table 2) (Flores et al., 2002).

It is worth noting that the remarkable downregulation of Bcl-2 and IGF1R in the present study could imply that these genes have been the potential targets of cancer drug developments (Chipuk and Green, 2008; Zhou et al., 2017).

In conclusion, as far as the authors of the present article are concerned, these findings are novel and address the apoptotic potential of the new pyrrolidine-2-Carboxamide derivative for the first time. The Pyrrolidine-2-Carboxamide derivative was shown to induce apoptosis in HepG2 cells. It also affected the expression of some genes involved 
in apoptosis pathways. However, further experiments are required to evaluate these types of compounds to examine their pharmacological properties as the sources of pharmacologically valuable products against human cancer cells.

\section{Funding Statement Not applicable.}

\section{Acknowledgements}

This project was funded through the Rafsanjan University of Medical Sciences. The authors thank the molecular medicine research center (MMRC) of RUMS of Iran for providing the required equipment for this work.

\section{References}

Chipuk JE, Green DR (2008). How do BCL-2 proteins induce mitochondrial outer membrane permeabilization. Trends Cell Bio, 18, 157-64.

Darehkordi A, Ramezani M (2017). One-pot synthesis of novel $(2 \mathrm{R}, 4 \mathrm{~S})$-N-aryl-4-hydroxy-1-(2,2,2-trifluoroacetyl) pyrrolidine-2-carboxamides via TiO-NPs and $\mathrm{Pd}(\mathrm{PPh})-\mathrm{Cl}$ catalysts and investigation of their biological activities. $\mathrm{Mol}$ Divers, 21, 305-15.

Ferreira CG, Epping M, Kruyt FA, et al (2002). Apoptosis: target of cancer therapy. Clin Cancer Res, 8, 2024-34.

Fesik SW (2005). Promoting apoptosis as a strategy for cancer drug discovery. Nat Rev Cancer, 5, 876.

Flores ER, Tsai KY, Crowley D, et al (2002). p63 and p73 are required for $\mathrm{p} 53$-dependent apoptosis in response to DNA damage. Nature, 416, 560.

Hanahan D, Weinberg RA (2000). The hallmarks of cancer. Cell, 100, 57-70.

Hersey P, Zhang XD (2001). How melanoma cells evade trail-induced apoptosis. Nat Rev Cancer, 1, 142.

Hudlicky M (1979). Hydrogenolysis of carbon-fluorine bonds in catalytic hydrogenation. J Fluor Chem, 14, 189-99.

Igney FH, Krammer PH (2002). Death and anti-death: tumour resistance to apoptosis. Nat Rev Cancer, 2, 277.

Marnett LJ, Plastaras JP (2001). Endogenous DNA damage and mutation. Trends Genet, 17, 214-21.

Martinvalet D, Zhu P, Lieberman JG (2005). A induces caspase-independent mitochondrial damage, a required first step for apoptosis. Immunity, 22, 355-70.

Mirzaei MR, Najafi A, Arababadi MK, et al (2014). Altered expression of apoptotic genes in response to OCT4B1 suppression in human tumor cell lines. Tumor Bio, 35, 9999-10009.

Moy KA, Jiao L, Freedman ND, et al (2013). Soluble receptor for advanced glycation end products and risk of liver cancer. Hepatology, 57, 2338-45.

Norbury CJ, Hickson ID (2001). Cellular responses to DNA damage. Annu Rev Pharmacol Toxicol, 41, 367-401.

Polshettiwar V, Varma RS (2010). Green chemistry by nano-catalysis. Green Chem, 12, 743-54.

Ramezani M, Ramezani M, Hassanshahi G, et al (2017). Does the novel class of (2R, 4S)-N-(2, 5-Difluorophenyl)4-Hydroxy-1-(2, 2, 2-Trifluoroacetyl) Pyrrolidine-2Carboxamide's have any effect on cell viability and apoptosis of human hepatocellular carcinoma cells?. Int J Cancer Manag, 10, In Press:e8413.

RCall JA, Eckhardt SG, Camidge DR (2008). Targeted manipulation of apoptosis in cancer treatment. Lancet
Oncol, 9, 1002-11.

Reed JC (2008). Bcl-2-family proteins and hematologic malignancies: history and future prospects. Blood, 111, 3322-30.

Romero AH, Salazar J, López SE (2015). Synthesis of 2-(trifluoromethyl) benzo [b][1, 8] naphthyridin-4 $(1 \mathrm{H})$-one derivatives using trifluoroacetimidoyl chlorides. J Fluor Chem, 169, 32-7.

Rubio-Moscardo F, Blesa D, Mestre C, et al (2005). Characterization of $8 \mathrm{p} 21.3$ chromosomal deletions in B-cell lymphoma: TRAIL-R1 and TRAIL-R2 as candidate dosage-dependent tumor suppressor genes. Blood, 106, 3214-22.

ten Holte P, van Esseveldt BC, Thijs L, et al (2001). Synthesis of oxazolidinones by a solid-phase/activation cycloelimination (SP/ACE) Methodology. Eur J Org Chem, 2001, 2965-9.

Zhou X, Fang X, Jiang Y, et al (2017). Klotho, an anti-aging gene, acts as a tumor suppressor and inhibitor of IGF-1R signaling in diffuse large B cell lymphoma. J Hematol Oncol, 10, 37.

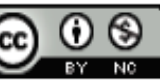

This work is licensed under a Creative Commons AttributionNon Commercial 4.0 International License. 